\title{
Gender Determination by Polymerase Chain Reaction Using Pulp Tissue of Deciduous Teeth Stored in Fresh Water and Natural Soil
}

\author{
Manju R Nair ${ }^{1}$, Veena Shetty ${ }^{2}$, Prachi Suman ${ }^{3}$, Shama Rao ${ }^{4}$, Muthtamil Sampath ${ }^{5}$, Ravi M Subrahmanya ${ }^{6}$
}

\begin{abstract}
Aim: The present study was carried out to assess the effectiveness of pulp tissue of deciduous teeth stored in fresh water and natural soil, as a source of nuclear DNA and its use for the determination of gender using polymerase chain reaction (PCR).

Materials and methods: One hundred and twenty extracted deciduous teeth were divided into two groups of 60 each and were stored in fresh water (group I) and natural soil (group II). These groups were divided into 3 subgroups (A, B, and C) of 20 each and stored for 3, 9, and 15 months, respectively, before subjecting for the PCR analysis. DNA was isolated and quantified. $X$ and $Y$ chromosomes were amplified by PCR and compared with the actual gender of the child. The data were analyzed using the Shapiro-Wilk test, the independent sample $t$-test, the paired $t$-test, and the chi-square test.

Results: The pulp tissue of teeth stored in natural soil showed significantly higher correct interpretation than that of the teeth stored in fresh water.

Conclusion: Even though the ability of determination of gender from the samples stored in fresh water and natural soil decreased with the prolongation of storage period, teeth stored in natural soil were found to be better than that of the ones stored in fresh water.

Clinical significance: The pulp tissue of deciduous teeth is effective for gender determination and that would be extremely helpful for forensic experts for the identification of markedly skeletonized bodies.

Keywords: Deciduous teeth, Gender determination, Polymerase chain reaction analysis, Pulp tissue.

World Journal of Dentistry (2020): 10.5005/jp-journals-10015-1772
\end{abstract}

\section{INTRODUCTION}

Forensic odontology is recognized as a specialty of dentistry that has been developing as a specialist discipline in the past few decades. Even though forensic odontology is most frequently associated with personal identification of the deceased in cases of mass disasters and natural calamities, the scope of this specialty is vast which includes assessment of bite mark injuries, orofacial injuries following assault or trauma, and child abuse injuries.

The important component of identification process includes the accurate determination of gender from the recovered skeletal remains whether it is partial or complete. The use of skeletal tissues as a mode of gender identification of the deceased dates back to our ancestry. Calcified tissues like bone and teeth have fundamentally the same chemical structure, although they vary in their method of development and microstructure. ${ }^{1-3}$

The dental characteristics play a major role for personal identification from the skeletal remains of children and preadolescents when there is lack of sufficiently developed sexual characteristics. ${ }^{4,5}$

Gender determination from teeth is very important in markedly degraded or skeletonized bodies. Even though many studies have been reported in the literature regarding determination of gender based on the external morphology of permanent teeth, there have been no methods to distinguish the sex based on the morphological characteristics of primary teeth. ${ }^{5}$

Teeth are the toughest and chemically very stable tissue in the human body. The enamel and dentin of human teeth act like a
${ }^{1}$ Department of Pediatric and Preventive Dentistry, AB Shetty Memorial Institute of Dental Sciences, NITTE (Deemed to be University), Mangaluru, Karnataka, India

${ }^{2,4}$ NITTE University Center for Stem Cell Research and Regenerative Medicine, Mangaluru, Karnataka, India

${ }^{3}$ Department of Pedodontics and Preventive Dentistry, AB Shetty Memorial Institute of Dental Sciences, NITTE (Deemed to be University), Mangaluru, Karnataka, India

${ }^{5}$ Department of Molecular Diagnostics and Research Center, Institute of Medical Sciences and SUM Hospital, Bhubaneswar, Odisha, India

${ }^{6}$ Department of Orthodontics and Dentofacial Orthopedics, NITTE (Deemed to be University), AB Shetty Memorial Institute of Dental Sciences, Mangaluru, Karnataka, India

Corresponding Author: Ravi M Subrahmanya, Department of Orthodontics and Dentofacial Orthopedics, NITTE (Deemed to be University), AB Shetty Memorial Institute of Dental Sciences, Mangaluru, Karnataka, India, e-mail: drmsravi@gmail.com

How to cite this article: Nair MR, Shetty V, Suman P, et al. Gender Determination by Polymerase Chain Reaction Using Pulp Tissue of Deciduous Teeth Stored in Fresh Water and Natural Soil. World J Dent 2020;11(5):402-407.

Source of support: Nil

Conflict of interest: None

shield to the DNA-rich pulp tissue present beneath the dentin from various environmental insults. ${ }^{6}$ Teeth can be considered as a rich source of both nuclear DNA and mitochondrial DNA. ${ }^{7}$ 
With the development of DNA analysis technique like polymerase chain reaction (PCR), gender determination from small samples of DNA can be analyzed easily and can be completed in a short period of time based on the detection of X-and Y-specific alphoid repeat sequence. Polymerase chain reaction has proved to be extremely effective owing to its increased specificity, sensitivity, and speed. ${ }^{8}$

Another most important variable to be considered while determining gender in forensic investigation is the time period and type of medium the teeth were in contact with prior to the analysis. The availability of DNA depends largely on these factors as the type of soil, water, and room temperature have a significant effect on the dehydration rate of the pulpal tissue. ${ }^{9}$

Hence, owing to the above-mentioned facts, the present study was undertaken to find out the efficacy of gender determination in children from the pulp tissue of exfoliated deciduous teeth stored in fresh water and natural soil for several months by PCR technique.

\section{Materials and Methods}

The study was conducted at AB Shetty Memorial Institute of Dental Sciences, Nitte (Deemed to be University), Mangaluru, India. A total of 120 teeth samples were collected from children between the age group of 10 to 13 years who reported to the Department of Pediatric and Preventive Dentistry for the extraction of their mobile deciduous teeth. Informed consent was obtained from the parents of all children. Clearance from Institutional Ethics Committee (Ref: NU/CEC/Ph. D-17/2014) was obtained. The deciduous teeth included were incisors, canines, and molar teeth and were selected by random sampling method. The teeth were divided into two groups of 60 each based on the medium of storage. Group I and group II samples were stored in fresh water and natural soil, respectively. Both the groups were further subdivided into three groups (A, B, and C) of 20 teeth each based on the duration of storage period.

Samples in groups IA, IB, and IC were stored in fresh water and samples in groups IIA, IIB, and IIC were stored in natural soil for a period of 3, 9, and 15 months, respectively, at room temperature. Coding and decoding of all samples were performed.

Immediately after the extraction of the teeth, they were decontaminated to eliminate external contaminants present on the external surface that could potentially affect the quality of the collected DNA. This was performed by washing with sterile-distilled water and stored in sterile-labeled bottles in the designated storage medium for the decided duration of time before the collection of pulp tissue. After the completion of storage in the respective media for the designated period of storage, the teeth samples were taken out and washed thoroughly using double-distilled water. Highly aseptic precautionary measures were taken while handling the teeth samples to avoid cross-contamination of samples.

Longitudinal sectioning of primary anterior teeth was performed using a high-speed handpiece cooled with distilled water and pulp tissue was collected using sterile disposable needle. Since the primary molar teeth selected for the study were with physiological mobility with total resorption of roots, the pulp tissue was collected from the pulp chamber by a sharp spoon excavator without sectioning the teeth. The collected pulp tissue from all the samples were stored in labeled bottles of Dulbecco's phosphatebuffer saline (PBS) and transported to the research lab and stored at $-20^{\circ} \mathrm{C}$ till the DNA extraction.

\section{DNA Isolation}

Isolation of DNA from the pulp tissue was performed using the Mini NucleoSpin Tissue kit (DSS Takara Bio India Pvt. Ltd.). The tissue sample was placed in a microcentrifuge tube of $1.5 \mathrm{~mL}$, and 180 $\mu \mathrm{L}$ of buffer $\mathrm{T} 1$ was added to $25 \mu \mathrm{L}$ of proteinase $\mathrm{K}$ solution and vortexed. Care was taken that the sample was completely covered with the lysis solution. The samples were then incubated at $56^{\circ} \mathrm{C}$ until complete lysis was obtained. Samples were then vortexed vigorously and incubated at $70^{\circ} \mathrm{C}$ for 10 minutes, and $600 \mu \mathrm{L}$ of buffer was added and centrifuged at 11,000 rpm for 1 minute. ${ }^{5}$

\section{DNA Quantification and Amplification}

The isolated DNA from the pulp tissue of each sample was then quantified using Bio Spectrometer to analyze the amount of DNA in $\mu \mathrm{g} / \mathrm{mL}$ obtained from the samples of each of the groups I and II. In the present study, two sets of oligonucleotide primers were used. ${ }^{5}$ Heat stable Taq DNA polymerase was provided in the PCR Buffer kit. The heating cycles of PCR were preheating at $95^{\circ} \mathrm{C}$ for 3 minutes and 35 heating cycles $\left(94^{\circ} \mathrm{C}\right.$ for 40 seconds, $55^{\circ} \mathrm{C}$ for 40 seconds, and $72^{\circ} \mathrm{C}$ for 40 seconds) using a thermocycler.

PCR Primers selected were:

Primers: $Y$ chromosome (size $172 \mathrm{bp})$ :

- Y11: 5'-ATGATAGAAACGGAAATATG.

- Y22: 5'-AGTAGAATGCAAAGGGCTC.

Primers: $X$ chromosome (size $131 \mathrm{bp})$ :

\section{- X1:5'-AATCATCAAATGGAGATTTG.}

- X2:5'-GTTCAGCTCTGTGAGTGAAA.

\section{Electrophoresis and Gender Determination}

The PCR products were then electrophoresed in $2 \%$ agarose gel at 80 to $100 \mathrm{~V}$ for 1 hour, ethidium bromide staining was performed, and amplified bands of $\mathrm{Y}$ - and $\mathrm{X}$-specific band sequences were examined using Gel DOC ${ }^{\mathrm{TM}}$ with Image Lab $^{\mathrm{TM}}$ software (Bio-Rad). The gender of the subjects was considered to be male when both $Y$ - and $X$-specific sequences were detected, but female when only $X$-specific sequences were detected (Figs 1 and 2).

\section{Statistical Analysis}

The normality of data was analyzed by the Shapiro-Wilk test. As the data followed a normal distribution, parametric tests were used to analyze the data. The independent sample $t$ test and paired $t$ test were used to check the mean differences among the groups. Chi-square test was used to compare the outcome between the

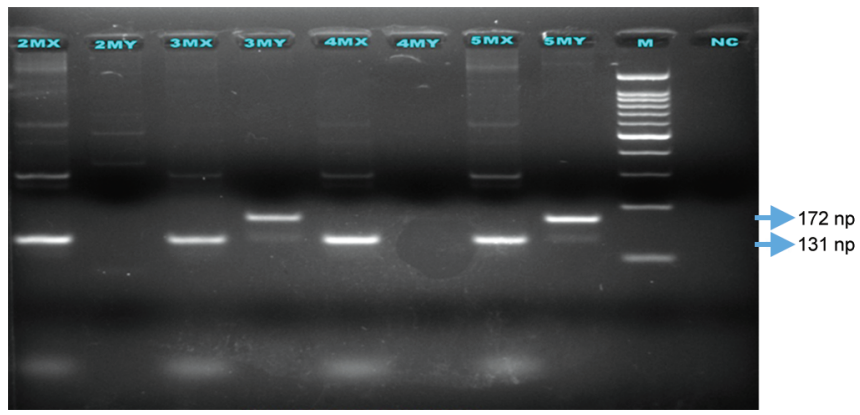

Fig. 1: Representative image showing polymerase chain reaction amplification of $X$ - and $Y$-specific chromosomes in a male sample. Both $X$ - and $Y$-specific DNA bands amplified. M, DNA ladder; NC, negative control; bp, base pairs 
study groups and different time intervals. The results of DNA quantification and PCR analysis of each group were statistically analyzed using SPSS (Statistical Package for Social Sciences) Version 24.0 (BM Corporation, Chicago, USA). Sensitivity, specificity, and diagnostic accuracy to detect the gender were assessed for each of the study group.

\section{Results}

In group IA, PCR analysis was possible only in 16 samples, out of which 13 samples (65.0\%) gave correct and 3 samples gave incorrect interpretation of the gender. There was no amplification noticed in the remaining four samples. In group IB, PCR analysis was performed only on 14 samples out of which 12 samples (60.0\%) showed correct and 2 samples showed incorrect interpretation of gender. In the remaining six samples, there was no amplification noticed in four samples and PCR analysis could not be carried out in two samples. In group IC, PCR analysis was possible only in seven samples out of which six samples (30.0\%) gave correct and one wrong interpretation of gender. In the remaining 13 samples, amplification was not noticed in 8 samples and PCR could not be carried out in 5 samples. The intra-group comparison in group I showed no statistical difference between groups IA and IB ( $p=$ $0.74)$ as well as groups IB and IC $(p=0.18)$. The group IA showed significantly more $(p=0.01)$ correct interpretation than that of group IC (Table 1 and Fig. 3).

In group IIA, out of the 18 samples subjected to PCR analysis 15 samples (75.0\%) showed correct and 3 samples showed incorrect interpretation of gender. There was no amplification noticed in the remaining two samples. In group IIB, PCR was performed in 16

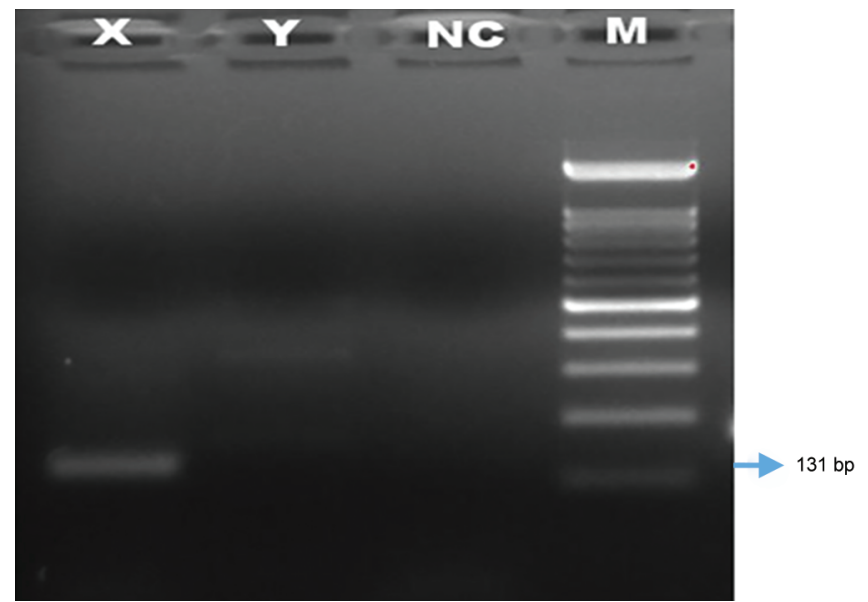

Fig. 2: Representative image showing polymerase chain reaction amplification of X-specific chromosome (female sample). X-specific DNA band observed but Y-specific DNA band not amplified. M, DNA ladder samples, out of which 13 (65.0\%) gave correct interpretation and 3 samples gave incorrect interpretation of gender. In the remaining four samples in this group, no amplification noticed in three samples and analysis was not carried out in one sample. In group IIC, 14 samples could be subjected to PCR and out of which 11 (55.0\%) gave the correct and 3 samples gave incorrect interpretation of gender. In the remaining six samples, no amplification was noticed in three samples and PCR analysis was not performed in three samples. Intragroup comparisons of group II showed no significant differences (Table 2 and Fig. 4).

The inter-group comparison of groups I and II showed that there was no statistically significant difference of groups IA and IB with that of group II samples. However, the group IC showed significantly less correct interpretation than that of the group IIA $(p=0.002)$ as well as group IIB $(p=0.04)$. There was no statistical difference between group IC and group IIC ( $p=0.20)$ (Table 3 and 4$)$.

The sensitivity, specificity, and diagnostic accuracy of PCR technique in gender determination in both the groups were analyzed. The PCR analysis of DNA obtained from group IA for 3 months showed sensitivity $87.5 \%$, specificity $75 \%$, and diagnostic accuracy of $81.25 \%$. Group IB showed sensitivity $87.5 \%$, specificity $83.33 \%$, and diagnostic accuracy $87.51 \%$. Group IC showed sensitivity $100 \%$, specificity $75 \%$, and diagnostic accuracy $85.71 \%$. Polymerase chain reaction showed very good sensitivity and diagnostic accuracy in group I on prolonged storage up to 15 months.

The PCR analysis of DNA obtained from group IIA for 3 months showed sensitivity $100 \%$, specificity $66.67 \%$, and diagnostic accuracy of $83.33 \%$. Group IIB showed sensitivity $85.71 \%$, specificity $77.78 \%$, and diagnostic accuracy $81.25 \%$. Group IIC showed sensitivity $100 \%$, specificity $50 \%$, and diagnostic accuracy $78.57 \%$. The specificity and diagnostic accuracy in group II decreases as the time period increased from 3 to 15 months (Table 5).

\section{Discussion}

Determination of gender can be refractory after catastrophic events, such as, fire, high-impact clashes, and explosions. Gender chromatin plays a major role in diagnosis, which are notoriously difficult when the body is fragmented or skeletonized..$^{10}$ Teeth have emerged as one of the most valuable postmortem specimens during forensic investigations, since many a times teeth are the only preserved remains available for forensic purposes.

In the present day scenario, with the existing socioeconomic conditions, children are more vulnerable or are more at risk for exploitation, abuse, or neglect. Since crime against children can happen anywhere, it is possible that in a forensic situation (either criminal or civil) the body of the deceased can be either left on the ground or thrown into the water bodies in a hurry or buried in the earth which might remain there for months or even years together. ${ }^{11}$

Table 1: Polymerase chain reaction results of group I

\begin{tabular}{|c|c|c|c|c|c|c|c|}
\hline & \multirow[b]{2}{*}{ Timeline } & \multirow[b]{2}{*}{$N$} & \multicolumn{4}{|c|}{ Interpretation, $N(\%)$} & \multirow[b]{2}{*}{$p$ value $e^{\#}$} \\
\hline & & & Correct & Incorrect & No amplification & Not done & \\
\hline \multirow[t]{6}{*}{ Fresh water (group I) } & 3 months & 20 & $13(65.0)$ & $3(15.0)$ & $4(20.0)$ & 0 & 0.74 (NS) \\
\hline & 9 months & 20 & $12(60.0)$ & $2(10.0)$ & $4(20.0)$ & $2(10.0)$ & \\
\hline & 3 months & 20 & $13(65.0)$ & $3(15.0)$ & $4(20.0)$ & 0 & $0.01^{*}$ \\
\hline & 15 months & 20 & $6(30.0)$ & $1(5.0)$ & $8(40.0)$ & $5(25.0)$ & \\
\hline & 9 months & 20 & $12(60.0)$ & $2(10.0)$ & $4(20.0)$ & $2(10.0)$ & 0.18 (NS) \\
\hline & 15 months & 20 & $6(30.0)$ & $1(5.0)$ & $8(40.0)$ & $5(25.0)$ & \\
\hline
\end{tabular}

*Significant at $p<0.05$ 


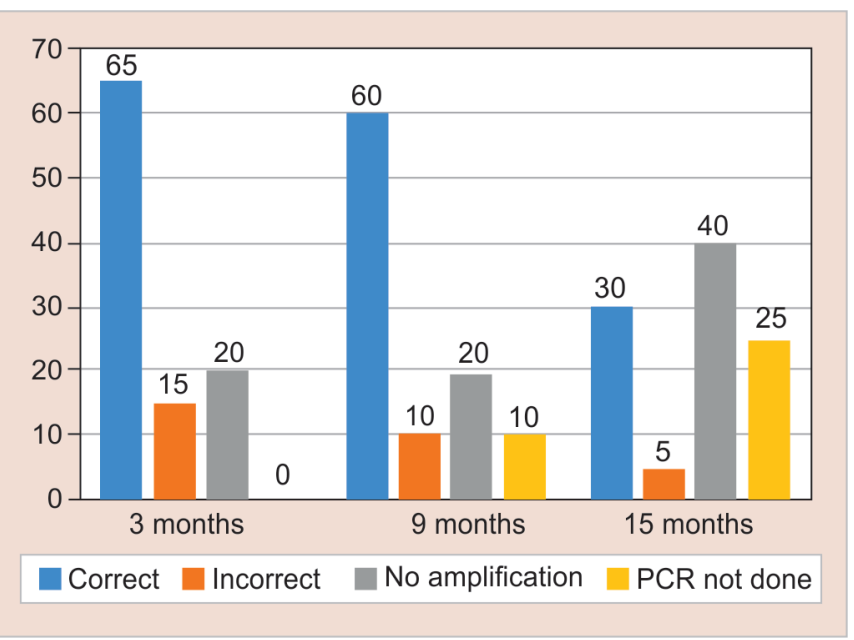

Fig. 3: Polymerase chain reaction results of group I

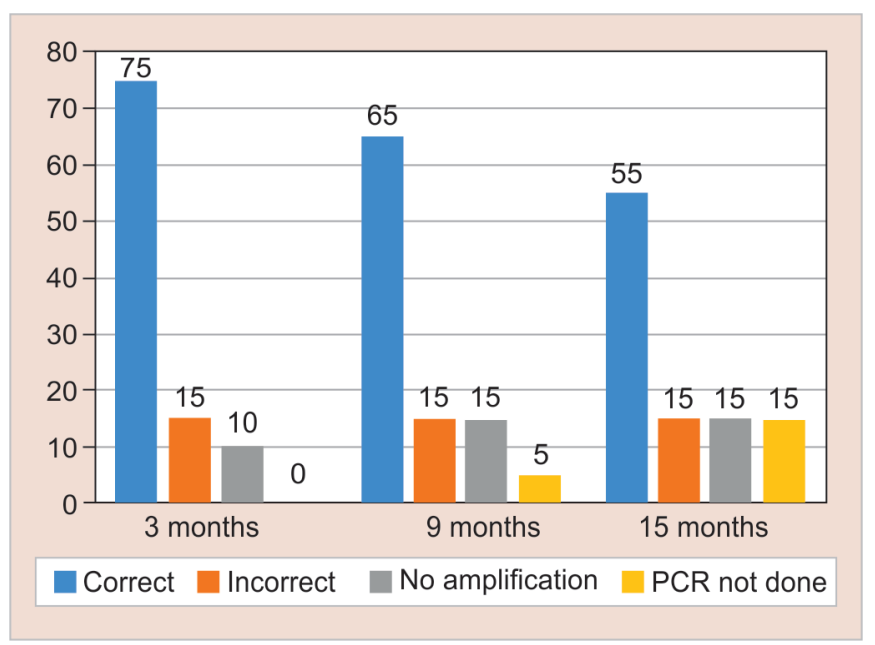

Fig. 4: Polymerase chain reaction results of group II

Table 2: Polymerase chain reaction results of group II

\begin{tabular}{|c|c|c|c|c|c|c|c|}
\hline \multirow[b]{2}{*}{ Groups } & \multirow[b]{2}{*}{ Timeline } & \multirow[b]{2}{*}{$N$} & \multicolumn{4}{|c|}{ Interpretation, $\mathrm{N}(\%)$} & \multirow[b]{2}{*}{$p$ value $\#$} \\
\hline & & & Correct & Incorrect ${ }^{5}$ & No amplification & Not done & \\
\hline \multirow[t]{6}{*}{ Natural soil (group II) } & 3 months & 20 & $15(75.0)$ & $3(15.0)$ & $2(10.0)$ & 0 & 0.88 (NS) \\
\hline & 9 months & 20 & $13(65.0)$ & $3(15.0)$ & $3(15.0)$ & $1(5.0)$ & \\
\hline & 3 months & 20 & $15(75.0)$ & $3(15.0)$ & $2(10.0)$ & 0 & 0.34 (NS) \\
\hline & 15 months & 20 & $11(55.0)$ & $3(15.0)$ & $3(15.0)$ & $3(15.0)$ & \\
\hline & 9 months & 20 & $13(65.0)$ & $3(15.0)$ & $3(15.0)$ & $1(5.0)$ & 0.83 (NS) \\
\hline & 15 months & 20 & $11(55.0)$ & $3(15.0)$ & $3(15.0)$ & $3(15.0)$ & \\
\hline
\end{tabular}

Hence, the present study was undertaken to assess the efficacy of pulp tissue of exfoliated deciduous teeth for gender determination by molecular analysis.

Determination of sex from the dental morphometric values of a single tooth is extremely difficult. The deciduous teeth show much less sexual dimorphism as compared to permanent teeth. Hence, sex identification from the external morphological characteristics of primary teeth is not reliable. ${ }^{12,13}$ So, one has to solely depend on the DNA obtained from the teeth for gender identification. Hence, in the present study, pulp tissue was used as a source of DNA to identify the gender by molecular analysis.

There are several methods which can be employed for DNA analysis obtained from the pulp tissue of the teeth like Southern blot test, RFLP analysis, Fluorescence Y chromosome test, etc. But since the development of PCR technique, its application in forensic investigations has been evaluated. $8,14,15$

Polymerase chain reaction techniques stand above all the previously mentioned techniques for gender determination because of its high rate of sensitivity and specificity as noted in the previous experiments. $^{5}$

Although there have been various studies performed on DNA analysis from pulp tissue of permanent teeth under various storage conditions in the literature, very few studies have been performed in the deciduous dentition estimating their storage under these conditions for a prolonged period of time. The environmental factors do have an influence on the stability of DNA since many times corpses or their pieces are frequently found carbonized, submersed in water, or buried in soil. A study in the literature had proved that the environmental factors can interfere in the amount of recovered DNA because of the degradation and can influence in the identification process. ${ }^{16}$ Hence, in the present study, in order to promote extreme degradation of pulp tissue, we mimicked extreme forensic conditions as per the studies carried out previously. 2,17,18

Primary teeth which were free of dental caries and showing pre-shedding mobility were extracted and selected for the study. The samples in groups I and II were stored in fresh water and natural soil, respectively, for the designated period of time before the PCR analysis. These media differ in their properties, temperature, $\mathrm{pH}$, and microbial load, hence they were chosen as storage media in the present study.

All the extracted teeth were decontaminated by washing under distilled water to remove the external contaminants which can affect the quality of DNA from the pulp tissue which correlates with the results of another study in $2017 .{ }^{19}$ Highly aseptic precautionary measures were taken using sterile instruments and disposable gloves while handling the teeth samples. The pulp tissue from the pulp chamber of primary teeth was collected using sterile disposable needle and spoon excavator. The collected pulp tissue samples were stored in Dulbecco's PBS in individualized and labeled Eppendorf tubes and then transported to the research lab and stored at $-20^{\circ} \mathrm{C}$ till the DNA extraction.

The first step in the laboratory processing for the PCR analysis is the isolation of DNA which was performed using Mini NucleoSpin tissue kit followed by quantification of DNA. Polymerase chain reaction analysis was carried out in all the teeth samples by denaturation, annealing, and extension. In the present study, PCR was used to amplify specific alphoid centromeric repeat sequence. Hence, this method allowed accurate gender determination by the detection of $X$ and $Y$ chromosome-specific alphoid repeat sequences which was in agreement with another study in the literature. ${ }^{20}$ 
Gender Determination from Pulp Tissue of Deciduous Teeth

Table 3: Inter-group comparison of results of polymerase chain reaction analysis

\begin{tabular}{|c|c|c|c|c|c|c|c|}
\hline \multirow[b]{2}{*}{ Groups } & \multirow[b]{2}{*}{ Timeline } & \multirow[b]{2}{*}{$N$} & \multicolumn{4}{|c|}{ Interpretation, $N(\%)$} & \multirow[b]{2}{*}{$p$ value } \\
\hline & & & Correct & Incorrect & No amplification & Not done & \\
\hline Group IA & 3 months & 20 & $13(65.0)$ & $3(15.0)$ & $4(20.0)$ & 0 & \\
\hline \multirow[t]{3}{*}{ Group II } & 3 months & 20 & $15(75.0)$ & $3(15.0)$ & $2(10.0)$ & 0 & 0.88 (NS) \\
\hline & 9 months & 20 & $13(65.0)$ & $3(15.0)$ & $3(15.0)$ & $1(5.0)$ & $1.00(\mathrm{NS})$ \\
\hline & 15 months & 20 & $11(55.0)$ & $3(15.0)$ & $3(15.0)$ & $3(15.0)$ & 0.44 (NS) \\
\hline Group IB & 9 months & 20 & $12(60.0)$ & $2(10.0)$ & $4(20.0)$ & $2(10.0)$ & \\
\hline \multirow[t]{3}{*}{ Group II } & 3 months & 20 & $15(75.0)$ & $3(15.0)$ & $2(10.0)$ & 0 & 0.43 (NS) \\
\hline & 9 months & 20 & $13(65.0)$ & $3(15.0)$ & $3(15.0)$ & $1(5.0)$ & 1.00 (NS) \\
\hline & 15 months & 20 & $11(55.0)$ & $3(15.0)$ & $3(15.0)$ & $3(15.0)$ & 1.00 (NS) \\
\hline Group IC & 15 months & 20 & $6(30.0)$ & $1(5.0)$ & $8(40.0)$ & $5(25.0)$ & \\
\hline \multirow[t]{3}{*}{ Group II } & 3 months & 20 & $15(75.0)$ & $3(15.0)$ & $2(10.0)$ & 0 & $0.002^{*}$ \\
\hline & 9 months & 20 & $13(65.0)$ & $3(15.0)$ & $3(15.0)$ & $1(5.0)$ & $0.04^{*}$ \\
\hline & 15 months & 20 & $11(55.0)$ & $3(15.0)$ & $3(15.0)$ & $3(15.0)$ & 0.20 (NS) \\
\hline
\end{tabular}

*Significant at $p<0.05$

Table 4: Interpretation of polymerase chain reaction results between groups I and II

\begin{tabular}{|c|c|c|c|c|c|c|c|}
\hline \multirow[b]{3}{*}{ Groups } & \multirow[b]{3}{*}{ Result } & \multicolumn{6}{|c|}{ Time period } \\
\hline & & \multicolumn{2}{|c|}{3 months } & \multicolumn{2}{|c|}{9 months } & \multicolumn{2}{|c|}{15 months } \\
\hline & & $N$ & $\%$ & $N$ & $\%$ & $N$ & $\%$ \\
\hline \multirow[t]{4}{*}{ Fresh water (group I) } & Correct match & 13 & 65 & 12 & 60 & 6 & 30 \\
\hline & Incorrect match & 3 & 15 & 2 & 10 & 1 & 5 \\
\hline & No amplification & 4 & 20 & 4 & 20 & 8 & 40 \\
\hline & Could not be done & 0 & 0 & 2 & 10 & 5 & 25 \\
\hline \multirow[t]{4}{*}{ Natural soil (group II) } & Correct match & 15 & 75 & 13 & 65 & 11 & 55 \\
\hline & Incorrect match & 3 & 15 & 3 & 15 & 3 & 15 \\
\hline & No amplification & 2 & 10 & 3 & 15 & 3 & 15 \\
\hline & Could not be done & 0 & 0 & 1 & 5 & 3 & 15 \\
\hline
\end{tabular}

Table 5: The sensitivity, specificity, and diagnostic accuracy in groups I and II

\begin{tabular}{lllll}
\hline \multicolumn{2}{c}{ Groups I and II } & Sensitivity (\%) & Specificity (\%) & Diagnostic accuracy (\%) \\
\hline Fresh water (group I) & 3 months & 87.5 & 75 & 81.25 \\
& 9 months & 87.5 & 83.33 & 85.71 \\
\multirow{2}{*}{ Natural soil (group II) } & 15 months & 100 & 75 & 85.71 \\
& 3 months & 100 & 66.67 & 83.33 \\
& 9 months & 85.71 & 77.78 & 81.25 \\
& 15 months & 100 & 50 & 78.57 \\
\hline
\end{tabular}

The results of the present study showed that both the medium and the period of storage have an impact on the quantity and quality of the retrieved DNA and hence affected the PCR results. Intra-group comparison of PCR results in teeth stored in fresh water showed that as the time period of storage increased from 3 to 9 and to 15 months, the number of teeth samples where PCR could be carried out decreased from 16 to 14 and to 7, respectively. The percentage of teeth samples which gave correct PCR results decreased from $65 \%$ at 3 months of storage to $30 \%$ at 15 months of storage in fresh water. The fresh water as a medium of storage has led to degradation of DNA on prolonged period and hence affected the PCR results. The samples which did not give the correct interpretation of gender could be due to non-retrieval of sufficient quantity of DNA or non-amplification of the DNA. This could be due to degradation of DNA caused by the autolytic processes in a wet state, hence on prolonged storage in wet environment DNA analysis is considered to be difficult. ${ }^{5,15}$

Intra-group comparison of PCR results in teeth stored in natural soil showed that as the time period of storage increased from 3 to 9 and up to 15 months, the number of samples which could be subjected to the PCR decreased from 18 to 16 to 14 , respectively. The percentage of samples which gave correct PCR results also decreased from 75 to $65 \%$ and to $55 \%$. This could be due to the composition of natural soil wherein decomposition can be completely inhibited or decreased due to diffusion of gases through the soil matrix. The DNA degradation speed is much less in natural soil. ${ }^{21}$

Inter-group comparison of both the groups showed that natural soil is a better medium of storage as compared to fresh water. In a wet state, DNA in the pulp tissue is degraded or fragmented and 
hence detection of $X$ and $Y$ chromosome-specific DNA by PCR becomes impossible. $^{5}$

The non-amplification of the samples in both the groups could be attributed to the effect of these two media on the quantity and quality of DNA. Regarding the first media even though the exact mechanism by which the water affects DNA recovery is not clear, some components present in aquatic ecosystems have already been reported as being able to degrade genetic material (microbial growth, humidity) ${ }^{22}$ or inhibit the Taq DNA polymerase enzyme (humic acid). Thus, its inhibition is a hindrance to PCR. ${ }^{17}$ Teeth samples in which PCR analysis was not carried out did not yield sufficient quantity of DNA. In the present study, we used mini kit for the isolation of DNA. The results would have been better using a micro-isolation kit wherein less volume of tissue content gives more yield of DNA.

Regarding the second medium, burying the teeth in natural soil can lead to infiltration of microbial growth in the pulp cavity which further causes degradation of DNA of pulp tissue to such a degree that amplification was not possible. ${ }^{5}$

The $100 \%$ diagnostic accuracy of gender determination by PCR in both the groups was not achieved. The overall decrease in success rate on prolonged storage of teeth samples in both the groups could be due to loss of tissue during pulp extirpation, contamination of the pulp tissue while collection, time lapse for the procedure, variation in the pulp volume, lack of adequate quantity of DNA to perform PCR technique and root resorption in the deciduous teeth. ${ }^{23}$

Other factors could be due to human errors, such as, mislabeling, presence of exogenous DNA. Technical errors like long annealing temperature or use of long primers while doing the PCR also could be one of the reasons. ${ }^{24}$

\section{ConCLUSION}

Within the limitations of the study, it may be concluded that the quality and quantity of DNA extracted from the pulp tissue of teeth stored in natural soil was better compared to that of teeth stored in fresh water at different time periods. Hence, the percentage of correct determination of gender by PCR technique was higher in teeth stored in natural soil compared to that stored in fresh water. Hence, the pulp tissue of deciduous teeth can be used as a source for gender determination and that would be extremely helpful for forensic experts for the identification of markedly skeletonized bodies.

\section{References}

1. Schwinger E, Rakebrand E, Müller HJ, et al. Y-body in hair roots. Human genetik 1971;12(1):79-80. DOI: 10.1007/BF00291039.

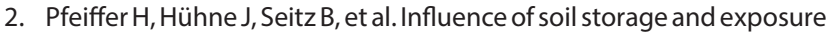
period on DNA recovery from teeth. Int J Legal Med 1999;112(2):142144. DOI: $10.1007 / \mathrm{s} 004140050219$.

3. Williams $D$, Lewis $M$, Franzen $T$, et al. Sex determination by PCR analysis of DNA extracted from incinerated, deciduous teeth. Sci Just: J Foren Sci Soc 2004;44(2):89-94. DOI: 10.1016/S1355-0306(04) 71694-9.

4. Pötsch L, Meyer U, Rothschild S, et al. Application of DNA techniques for identification using human dental pulp as a source of DNA. Int J Legal Med 1992;105(3):139-143. DOI: 10.1007/BF01625165.
5. Murakami H, Yamamoto Y, Yoshitome K, et al. Forensic study of sex determination using PCR on teeth samples. Acta Med Okayama 2000;54(1):21-32.

6. Sweet $D$, Hildebrand D. Recovery of DNA from human teeth by cryogenic grinding. J Foren Sci 1998;43(6):1199-1202. DOI: 10.1520/ JFS14385J.

7. Mörnstad H, Pfeiffer $\mathrm{H}$, Yoon $\mathrm{C}$, et al. Demonstration and semiquantification of mtDNA from human dentine and its relation to age. Int J Legal Med 1999;112(2):98-100. DOI: 10.1007/s004140050209.

8. Akane A, Shiono $\mathrm{H}$, Matsubara $\mathrm{K}$, et al. Sex identification of forensic specimens by polymerase chain reaction (PCR): two alternative methods. Forensic Sci Int 1991;49(1):81-88. DOI: 10.1016/03790738(91)90174-H.

9. Battepati PM, Shodan M. Gender determination using primary teeth: a polymerase chain reaction (PCR) study. J Dent Oral Hyg 2013;5:77-82.

10. Jeffreys AJ, Wilson $V$, Thein SL. Hypervariable 'minisatellite'regions in human DNA. Nature 1985;314(6006):67-73. DOI: 10.1038/ $314067 a 0$.

11. Mehendiratta M, Jain K, Boaz K, et al. Estimation of time elapsed since the death from identification of morphological and histological timerelated changes in dental pulp: an observational study from porcine teeth. J Forensic Dent Sci 2015;7(2):95. DOI: 10.4103/0975-1475. 154594.

12. De Vito C, Saunders SR. A discriminant function analysis of deciduous teeth to determine sex. J Foren Sci 1990;35(4):845-858. DOI: 10.1520/ JFS12897J.

13. Cardoso HF. Testing discriminant functions for sex determination from deciduous teeth. J Forensic Sci 2010;55(6):1557-1560. DOI: 10.1111/j.1556-4029.2010.01530.x.

14. Yamamoto Y. Sex identification of bloodstains by polymerase chain reaction (PCR) of Y-chromosome-specific alphoid repeat sequences. Acta Criminologiae et Medicinae Legalis Japonica 1991;57:5-5.

15. Reynolds R, Varlaro J. Gender determination of forensic samples using PCR amplification of ZFX/ZFY gene sequences. J Foren Sci 1996;41(2):279-286. DOI: 10.1520/JFS15427J.

16. Schwartz TR, Schwartz EA, Mieszerski L, et al. Characterization of deoxyribonucleic acid (DNA) obtained from teeth subjected to various environmental conditions. J Foren Sci 1991;36(4):979-990. DOI: $10.1520 / J F S 13113$ J.

17. Burger J, Hummel S, Herrmann B, et al. DNA preservation: a microsatellite-DNA study on ancient skeletal remains. Electrophoresis: An Int J 1999;20(8):1722-1728. DOI: 10.1002/ (SICI)1522-2683(19990101)20:8<1722::AID-ELPS1722>3.0.CO;2-4.

18. Alonso A, Anđelinović Š, Martín P, et al. DNA typing from skeletal remains: evaluation of multiplex and megaplex STR systems on DNA isolated from bone and teeth samples. Croat Med J 2001;42(3): 260-266.

19. Kholief M, El Shanawany S, Gomaa R. Sex determination from dental pulp DNA among Egyptians. Egypt J Forensic Sci 2017;7(1):29.

20. Witt M, Erickson RP. A rapid method for detection of Y-chromosomal DNA from dried blood specimens by the polymerase chain reaction. Hum Genet 1989;82(3):271-274. DOI: 10.1007/BF00291168.

21. Tumer AR, Karacaoglu E, Namli A, et al. Effects of different types of soil on decomposition: an experimental study. Leg Med 2013;15(3): 149-156. DOI: 10.1016/j.legalmed.2012.11.003.

22. Bender K, Farfán MJ, Schneider PM. Preparation of degraded human DNA under controlled conditions. Forensic Sci Int 2004;139(2-3): 135-140. DOI: 10.1016/j.forsciint.2003.10.003.

23. Haertig A, Krainic K, Vaillant JM, et al. Medicolegal identification: teeth and blood groups (author's transl). Rev Stomatol Chir Maxillofac 1980;81(6):361-363.

24. Hanaoka Y, Minaguchi K. Sex determination from blood and teeth by PCR amplification of the alphoid satellite family. Journal of Forensic Science 1996;41(5):855-858. DOI: 10.1520/JFS14010J. 